\title{
Temperature Effect on Yield and Yield Components of Different Rice Cultivars in Flowering Stage
}

\author{
R. Ghadirnezhad ${ }^{1}$ and A. Fallah ${ }^{2}$ \\ ${ }^{1}$ Department of Agronomy, Ghaemshahr Branch, Islamic Azad University, Ghaemshahr, Iran \\ ${ }^{2}$ Rice Research Institute of Amol, Mazandaran 46191-91951, Iran
}

Correspondence should be addressed to R. Ghadirnezhad; mina_620062@yahoo.com

Received 9 January 2014; Accepted 28 April 2014; Published 18 May 2014

Academic Editor: Othmane Merah

Copyright (c) 2014 R. Ghadirnezhad and A. Fallah. This is an open access article distributed under the Creative Commons Attribution License, which permits unrestricted use, distribution, and reproduction in any medium, provided the original work is properly cited.

\begin{abstract}
In order to study the effect of cold stress in flowering stage on yield and yield components of different rice cultivars, an experiment was performed as split plot factorial based on completely randomized design (CRD) in greenhouse of deputy of rice research institute of Iran (Amol) in 2010, in three repetitions. Treatment included 5 varieties as main factors that included cultivars of shirudi, fajr, local tarom, hybrid, and line 843 . Two levels of temperatures $T_{1}\left(13^{\circ} \mathrm{C}\right.$, stress temperature $)$ and $T_{2}\left(32^{\circ} \mathrm{C}\right.$, normal temperature, control) along with flowering stage were selected as two subfactors. Three seedlings were planted in each plot. The cold stress was done in flowering stage with holding pots at $13^{\circ} \mathrm{C}$ for 15 days. Results showed that low temperature had significant effect in level of 1 percent on all characters, such as the number of panicles, the length of panicle, and the number of full, empty, and total grains; as a result, yield had caused significant reduction. Interaction between temperature and varieties showed that most tolerant variety in relation to temperature stress along with least percentage yield (19\%) is shirudi variety and the most sensitive one with most percentage of yield decrease (29\%) was local tarom variety.
\end{abstract}

\section{Introduction}

Rice (Oryza sativa) is a monocot crop. It is a cereal grain and the most widely consumed staple food for a large part of the world's human population, especially in Asia. After maize (corn), it has the second-highest worldwide production, according to data from 2010. Rice can be grown in different environments depending upon water availability and temperature conditions [1]. Cold stress is a common problem in rice cultivation and affects global production as a crucial factor [2]. Rice is a cold-sensitive plant that originated from tropical or subtropical zones. When low temperature occurs during the reproductive stages, it can cause serious yield and yield components losses [3]. The optimum temperature for rice cultivation is between $25^{\circ} \mathrm{C}$ and $35^{\circ} \mathrm{C}$, and in temperate regions, rice growth is impressed by limited period that favors its growth [4].

Exposure to cold temperature affects all phonological stages of rice and lower grain production and yield, too. Low temperature in vegetative stage can cause slow growth and reduce seedling vigor [5] low number of seedlings, reduce tillering [6] increase plant mortality $[3,7,8]$ increase the growth period [9] and in reproductive stage, it can cause to produc panicle sterility and lower grain production and yield [6].

Critical stages for cold damage include germination, booting, flowering, and filling stages [10]. Since the most sensitive stage for cold harm is the flowering stage, which occurs 10-12 days prior to heading, our objective of this study is to evaluate the effect of cold stress on yield and yield components in flowering stages and identify the Iranian current rice crop resistant and sensitive cultivars.

\section{Materials and Methods}

The experiment was performed as split plot factorial based on completely randomized design (CRD) in Greenhouse of Deputy of Rice Research Institute of Iran (Amol) in 2010, in three repetitions. This treatment included 5 varieties 
TABLE 1: Sources of variations of yield and yield components.

\begin{tabular}{|c|c|c|c|c|c|c|c|}
\hline S.O.V & df & $\begin{array}{c}\text { Panicle } \\
\text { number/hill } \\
(\mathrm{cm})\end{array}$ & $\begin{array}{l}\text { Panicle } \\
\text { length/hill } \\
(\mathrm{cm})\end{array}$ & $\begin{array}{l}\text { Full grain } \\
\text { number/hill }\end{array}$ & $\begin{array}{l}\text { Empty grain } \\
\text { number/hill }\end{array}$ & $\begin{array}{l}\text { Total } \\
\text { grain/hill }\end{array}$ & $\begin{array}{c}\text { Yield } \\
\text { (gm/hill) }\end{array}$ \\
\hline Cultivar factor & 4 & $106.8^{* *}$ & $19.89^{* *}$ & $112.82^{* *}$ & $151494.7^{* *}$ & $156662^{* *}$ & $215.8^{* *}$ \\
\hline Error A & 10 & 29 & 71.15 & 1426.76 & 13948.7 & 17314.8 & 581.2 \\
\hline Growth stage factor & 4 & $18.77^{* *}$ & $11.29^{* *}$ & $4269.82^{* *}$ & $27148.8^{* *}$ & $2851.3^{* *}$ & $251.2^{* *}$ \\
\hline Temperature factor & 1 & $181.5^{* *}$ & $95.36^{* *}$ & $117264^{* *}$ & $18627.6^{* *}$ & $574370^{* *}$ & $357.2^{* *}$ \\
\hline Growth stage $\times$ temperature interaction & 4 & $31.86^{* *}$ & $11.13^{* *}$ & $3235.15^{* *}$ & $56684.02^{* *}$ & $1091.2^{* *}$ & $53.16^{* *}$ \\
\hline Variety $\times$ growth stage interaction & 16 & $84.98^{* *}$ & $9.94^{* *}$ & $2822.8^{* *}$ & $279182.9^{* *}$ & $2720.7^{* *}$ & $120.8^{* *}$ \\
\hline Cultivar $\times$ temperature interaction & 4 & 7.41 & $3.28^{* *}$ & $6637.30^{* *}$ & $126981.2^{* *}$ & $5494.1^{* *}$ & $85.12^{* *}$ \\
\hline $\begin{array}{l}\text { Cultivar } \times \text { temperature } \times \text { growth stage } \\
\text { interaction }\end{array}$ & 16 & $139.2^{* *}$ & $8.17^{* *}$ & $5812.32^{* *}$ & $733214.2^{* *}$ & $4543.7^{* *}$ & $53.72^{* *}$ \\
\hline Error B & 90 & 2.27 & 7.2 & 10.47 & 5.9 & 11.29 & 7.8 \\
\hline $\mathrm{CV}$ & - & 20.2 & 13.4 & 14.2 & 15.2 & 16.8 & 11.2 \\
\hline
\end{tabular}

Ns: nonsignificant, $*$ and $* *$ significant in probability levels of $5 \%$ and $1 \%$, respectively.

TABLE 2: Effect of cultivar on yield and yield components across temperature.

\begin{tabular}{|c|c|c|c|c|c|c|}
\hline Cultivar & $\begin{array}{c}\text { Panicle } \\
\text { number/hill }(\mathrm{cm})\end{array}$ & $\begin{array}{c}\text { Panicle } \\
\text { length/hill }(\mathrm{cm})\end{array}$ & $\begin{array}{c}\text { Full grain } \\
\text { number/hill }\end{array}$ & $\begin{array}{l}\text { Empty grain } \\
\text { number/hill }\end{array}$ & Total grain/hill & $\begin{array}{c}\text { Yield } \\
\text { (gm/hill) }\end{array}$ \\
\hline Shirudi & $5.93^{\mathrm{ab}}$ & $19.32^{\mathrm{ab}}$ & $317.83^{\mathrm{a}}$ & $50.80^{\mathrm{b}}$ & $366.24^{\mathrm{a}}$ & $80.63^{\mathrm{a}}$ \\
\hline Fajr & $5.64^{\mathrm{ab}}$ & $20.48^{\mathrm{a}}$ & $182.29^{c}$ & $57.73^{\mathrm{b}}$ & $212.71^{\mathrm{c}}$ & $73.73^{\mathrm{b}}$ \\
\hline Tarom & $3.61^{\mathrm{c}}$ & $20.5^{\mathrm{a}}$ & $147.20^{\mathrm{d}}$ & $80.56^{\mathrm{a}}$ & $196.63^{\mathrm{d}}$ & $69.72^{\mathrm{d}}$ \\
\hline Line 843 & $4.93^{\mathrm{b}}$ & $20.78^{\mathrm{a}}$ & $252.5^{\mathrm{b}}$ & $52.93^{\mathrm{b}}$ & $310.30^{\mathrm{b}}$ & $72.46^{\mathrm{c}}$ \\
\hline Hybrid & $4.93^{\mathrm{b}}$ & $18.96^{\mathrm{b}}$ & $160.77^{\mathrm{c}}$ & $49^{c}$ & $226.37^{\mathrm{c}}$ & $71.95^{\mathrm{c}}$ \\
\hline
\end{tabular}

Distinct letters in the row indicate significant differences according to Tukey's test $(P \leq 0.01)$.

as main factor that include cultivars of shirudi, fajr, local tarom, hybrid, and line 843. Two levels of temperatures $T_{1}$ $\left(13^{\circ} \mathrm{C}\right.$, stress temperature $)$ and $T_{2}\left(32^{\circ} \mathrm{C}\right.$, normal temperature, control) along with flowering stage were selected as two subfactors. Three seedlings were planted in each plot. The cold stress was done in flowering stage with holding pots at $13^{\circ} \mathrm{C}$ for 15 days. $13^{\circ} \mathrm{C}$ temperature treatment was adjusted with cooler installation and relative humidity was maintained constantly between 70 and 80 percent by wetting bottomless sack of greenhouse. The normal temperature of $32^{\circ} \mathrm{C}$ was adjusted by split cooler installation and temperature setting thermostat and relative humidity was maintained between 80 and 85 percent.

The number of panicles in a hill was obtained with counting panicles in a hill. In order to measure the length of panicle $(\mathrm{cm})$, all panicles of hill were measured from the location of the panicle nodes to the panicle head with a ruler and then average values were recorded. Then, all grains of panicles were separated and the number of full and empty grains was counted and with the sum of them, the total number of seeds was obtained. By weighting the full and healthy grains of panicles, yield in hill was evaluated. All statics were performed with SAS program (Version 6.2) and MSTAT-C (Version 2.1). The mean comparisons were performed by the Duncan multiple range test in significance level of 1 percent.

\section{Results and Discussion}

As shown in Table 1, cultivar, growth stage, and temperature effects and their interactions on all treatments, such as the number of panicles, the length of panicle, the number of full, empty, total grains, and yield, were significant in level of 1 percent (Table 1).

As shown in Table 2, the maximum number of panicles was obtained in shirudi and fajr cultivars, respectively (5.93 and 5.64), and the minimum one was related to local tarom (3.61). The maximum amount of the length of panicle was obtained in line 843, local tarom, and fajr cultivars, respectively $(20.78,50.5$, and 20.48$)$ and the minimum one was related to hybrid cultivar (18.96). The maximum number of full grains was achieved in shirudi cultivar (317.83) and the minimum of it was obtained in tarom cultivar (182.29). The maximum and minimum numbers of empty grains were related to tarom and hybrid cultivars, respectively $(80.56,49)$. The maximum and minimum numbers of total grains were related to shirudi and tarom cultivars, respectively (366.24, 196.63). The shirudi and tarom cultivars were obtained by maximum and minimum yield, respectively $(80.63,69.72)$, gr per hill (Table 2).

As shown in Table 3, the temperature had significant effect on all treatments, so that the maximum value of each trait was obtained in normal temperature $\left(T_{2}\right)$ and the minimum one was related to stress temperature $\left(T_{1}\right)$. 
TABLE 3: Temperature effect on yield and yield components across varieties.

\begin{tabular}{lcccccc}
\hline Temperature & $\begin{array}{c}\text { Panicle number/hill } \\
(\mathrm{cm})\end{array}$ & $\begin{array}{c}\text { Panicle length/hill } \\
(\mathrm{cm})\end{array}$ & $\begin{array}{c}\text { Full grain } \\
\text { number/hill }\end{array}$ & $\begin{array}{c}\text { Empty grain } \\
\text { number/hill }\end{array}$ & $\begin{array}{c}\text { Total grain/hill } \\
(\mathrm{gm} / \mathrm{hill})\end{array}$ \\
\hline$T_{2}$ & $6.2^{\mathrm{a}}$ & $20.7^{\mathrm{a}}$ & $246.4^{\mathrm{a}}$ & $24.0^{\mathrm{b}}$ & $323.3^{\mathrm{a}}$ & $100.65^{\mathrm{a}}$ \\
$T_{1}$ & $4.0^{\mathrm{b}}$ & $19 .^{\mathrm{b}}$ & $175.9^{\mathrm{b}}$ & $72.92^{\mathrm{a}}$ & $199.5^{\mathrm{b}}$ & $75.80^{\mathrm{b}}$ \\
\hline
\end{tabular}

Distinct letters in the row indicate significant differences according to Tukey's test $(P \leq 0.01)$.

$T_{2}: 32^{\circ} \mathrm{C}, T_{1}: 13^{\circ} \mathrm{C}$.

TABLE 4: Interactive effects between cultivar and temperature on yield and yield components.

\begin{tabular}{|c|c|c|c|c|c|c|}
\hline Treatment & $\begin{array}{c}\text { Panicle } \\
\text { number/hill }(\mathrm{cm})\end{array}$ & $\begin{array}{l}\text { Panicle length/hill } \\
(\mathrm{cm})\end{array}$ & $\begin{array}{c}\text { Full grain } \\
\text { number/hill }\end{array}$ & $\begin{array}{l}\text { Empty grain } \\
\text { number/hill }\end{array}$ & $\begin{array}{c}\text { Total } \\
\text { grain/hill }\end{array}$ & $\begin{array}{c}\text { Yield } \\
\text { (gm/hill) }\end{array}$ \\
\hline $\mathrm{V}_{1} T_{2}$ & $5.80^{\mathrm{abc}}$ & $20.55^{\mathrm{a}}$ & $376.21^{\mathrm{a}}$ & $115.1^{\mathrm{a}}$ & $452.07^{\mathrm{a}}$ & $25.4^{\mathrm{a}}$ \\
\hline $\mathrm{V}_{1} T_{1}$ & $4.06^{\mathrm{a}}$ & $18.09^{\mathrm{a}}$ & $263.33^{c}$ & $46^{\mathrm{e}}$ & $286.13^{d}$ & $20.4^{\mathrm{f}}$ \\
\hline $\mathrm{V}_{2} T_{2}$ & $6.43^{\mathrm{abc}}$ & $19 / 67^{\mathrm{a}}$ & $183.25^{\mathrm{e}}$ & $36.5^{\mathrm{f}}$ & $220.0^{\mathrm{f}}$ & $24.8^{\mathrm{b}}$ \\
\hline $\mathrm{V}_{2} T_{1}$ & $4.80^{\mathrm{abcd}}$ & $18.20^{\mathrm{a}}$ & $181.26^{\mathrm{ef}}$ & $23.73^{\mathrm{g}}$ & $204.93^{\mathrm{g}}$ & $18.2^{\mathrm{h}}$ \\
\hline $\mathrm{V}_{3} T_{2}$ & $7.07^{\mathrm{ab}}$ & $21.25^{\mathrm{a}}$ & $226.0^{\mathrm{d}}$ & $82.92^{\mathrm{c}}$ & $338.33^{\mathrm{b}}$ & $22.5^{\mathrm{d}}$ \\
\hline $\mathrm{V}_{3} T_{1}$ & $4.33^{\mathrm{bcd}}$ & $19.80^{\mathrm{a}}$ & $38.40^{\mathrm{h}}$ & $24.93^{\mathrm{g}}$ & $114.4^{\mathrm{i}}$ & $15.8^{j}$ \\
\hline $\mathrm{V}_{4} T_{2}$ & $7.2^{\mathrm{a}}$ & $21.70^{\mathrm{a}}$ & $282^{\mathrm{b}}$ & $103.33^{\mathrm{b}}$ & $385.66^{c}$ & $22.2^{c}$ \\
\hline $\mathrm{V}_{4} T_{1}$ & $4.66^{\mathrm{abcd}}$ & $19.85^{\mathrm{a}}$ & $282^{\mathrm{b}}$ & $103.33^{\mathrm{b}}$ & $385.66^{c}$ & $17 / 4^{\mathrm{h}}$ \\
\hline $\mathrm{V}_{5} T_{2}$ & $4.8^{\mathrm{abcd}}$ & $20.90^{\mathrm{a}}$ & $177.66^{\mathrm{f}}$ & $64.80^{\mathrm{d}}$ & $235.93^{\mathrm{e}}$ & $22.1^{\mathrm{e}}$ \\
\hline $\mathrm{V}_{5} T_{1}$ & $2.4^{\mathrm{d}}$ & $20.06^{\mathrm{a}}$ & $143.56^{\mathrm{g}}$ & $13.20^{\mathrm{h}}$ & $157.33^{\mathrm{h}}$ & $16.5^{\mathrm{i}}$ \\
\hline
\end{tabular}

Distinct letters in the row indicate significant differences according to Tukey's test $(P \leq 0.01)$.

$\mathrm{V}_{1}$ : shirudi, $\mathrm{V}_{2}$ : fajr, $\mathrm{V}_{3}$ : local tarom, $\mathrm{V}_{4}$ : line 843 , and $\mathrm{V}_{5}$ : hybrid cultivars.

$T_{2}: 32^{\circ} \mathrm{C}, T_{1}: 13^{\circ} \mathrm{C}$.

The interactions effects table for cultivar in temperature (Table 4) shows that shirudi cultivar achieved the lowest reduction percent number of panicles (20\%) and it was the most resistant cultivar and hybrid cultivar obtained the highest one (50\%) and was a susceptible cultivar.

All experimental characteristics had not had significant difference for reduction of panicle length. Shirudi obtained the lowest reduction percent for number of full, empty, total grains and yield, respectively $(5 \%, 6 \%, 7 \%$, and 19\%), and local tarom achieved the most reduction percent for them, respectively $(83 \%, 73 \%, 66 \%$, and $29 \%)$, and for yield $(29 \%)$ and it was the most susceptible cultivars (Table 4).

\section{Conclusions}

Low temperature had significant effect in level of 1 percent on all treatments; the number of panicles, the length of panicle, the number of full, empty, total grains, and yield had caused significant reduction in them. The interaction temperature with varieties shows that most tolerant variety in relation to temperature stress along with least percentage yield (19\%) is shirudi variety and the most sensitive one with most percentage of yield decrease $(29 \%)$ is local tarom variety.

Cold stress at reproductive stage has had inappropriate effects on the yield of rice in Australia, China, and Korea since 2000 [2, 4, 6, 10-14]. Low temperature in the range of $15-19^{\circ} \mathrm{C}$ during the reproductive stage impairs microspore development and causes the production of sterile pollen grains, resulting in poor grain filling and high spikelet sterility [10] and reducing spikelet fertility and affecting grain quality
[13]. Several methods have been proposed to reduce the threat of low temperature, including substitution of cold-sensitive cultivars with cold tolerant ones, setting of sowing time, and selection of varieties with a growth duration permitting elusion of peak stress periods are some of the adaptive measures that will help in the reduction of adverse effects of low temperature.

\section{Conflict of Interests}

The authors declare that there is no conflict of interests regarding the publication of this paper.

\section{References}

[1] IRRI rice knowledge bank, 2013, Knowledgebank.irri.org.

[2] L. Zhou, Y. Zeng, G. Hu et al., "Characterization and identification of cold tolerant near-isogenic lines in rice," Breeding Science, vol. 62, pp. 196-201, 2012.

[3] T. C. Farrell, K. M. Fox, R. L. Williams, S. Fukai, and L. G. Lewin, "Minimising cold damage during reproductive development among temperate rice genotypes. II. Genotypic variation and flowering traits related to cold tolerance screening," Australian Journal of Agricultural Research, vol. 57, no. 1, pp. 89-100, 2006.

[4] B. G. De Los Reyes, S. J. Myers, and J. M. McGrath, "Differential induction of glyoxylate cycle enzymes by stress as a marker for seedling vigor in sugar beet (Beta vulgaris)," Molecular Genetics and Genomics, vol. 269, no. 5, pp. 692-698, 2003.

[5] M. G. Ali, R. E. L. Naylor, and S. Matthews, "Distinguishing the effects of genotype and seed physiological age on low 
temperature tolerance of rice (Oryza sativa L.)," Experimental Agriculture, vol. 42, no. 3, pp. 337-349, 2006.

[6] H. Shimono, T. Hasegawa, and K. Iwama, "Response of growth and grain yield in paddy rice to cool water at different growth stages," Field Crops Research, vol. 73, no. 2-3, pp. 67-79, 2002.

[7] A. R. Baruah, N. Ishigo-Oka, M. Adachi et al., "Cold tolerance at the early growth stage in wild and cultivated rice," Euphytica, vol. 165, no. 3, pp. 459-470, 2009.

[8] K. Fujino, H. Sekiguchi, T. Sato et al., "Mapping of quantitative trait loci controlling low-temperature germinability in rice (Oryza sativa L.)," Theoretical and Applied Genetics, vol. 108, no. 5, pp. 794-799, 2004.

[9] R. Alvarado and S. Hernaiz, "Antecedentesgeneralessobre el arroz en Chile," in Arroz Manejo Tecnológico, R. Alvarado, Ed., vol. 162 of Boletín INIA, p. 179, Instituto de InvestigacionesAgropecuarias INIA, Centro Regional de Investigación Quilamapu, Chillán, Chile, 2007.

[10] T. Satake, "Determination of the most sensitive stage to steriletypecool injury in rice plants," Bulletin of the Hokkaido National Agricultural Experiment Station, vol. 113, pp. 1-33, 1976.

[11] M. H. Lee, "Low temperature tolerance in rice: the Korean experience," in Proceedings of an International Workshop Increased lowlandrice Production in the Mekong region, pp. 109-117, Australian Center for International Agricultural Research, Canberra, Australia, Vientiane, Laos, October 2000.

[12] H. Shimono, T. Hasegawa, S. Fujimura, and K. Iwama, "Responses of leaf photosynthesis and plant water status in rice to low water temperature at different growth stages," Field Crops Research, vol. 89, no. 1, pp. 71-83, 2004.

[13] J. P. Suh, J. U. Jeung, J. I. Lee et al., "Identification and analysis of QTLs controlling cold tolerance at the reproductive stage and validation of effective QTLs in cold-tolerant genotypes of rice (Oryza sativa L.)," Theoretical and Applied Genetics, vol. 120, no. 5, pp. 985-995, 2010.

[14] L.-M. Xu, L. Zhou, Y.-W. Zeng et al., "Identification and mapping of quantitative trait loci for cold tolerance at the booting stage in a japonica rice near-isogenic line," Plant Science, vol. 174, no. 3, pp. 340-347, 2008. 


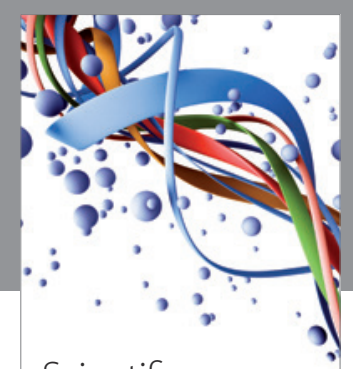

Scientifica
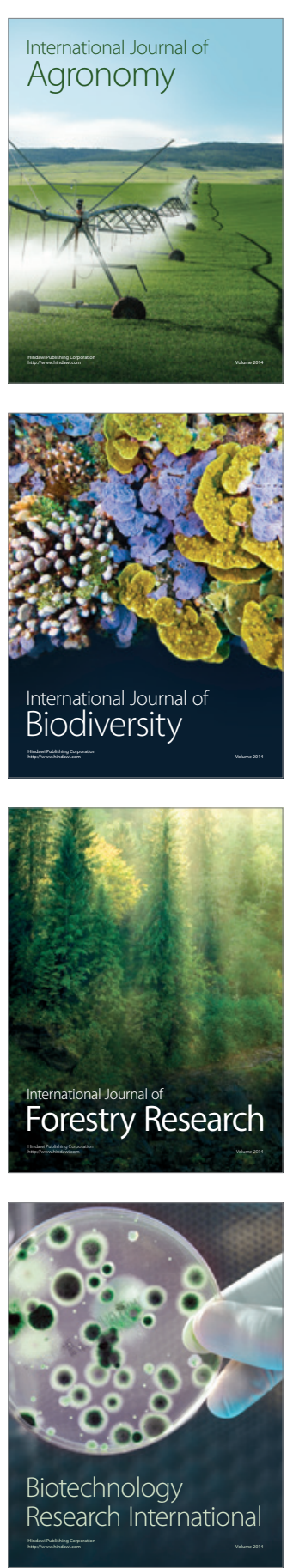
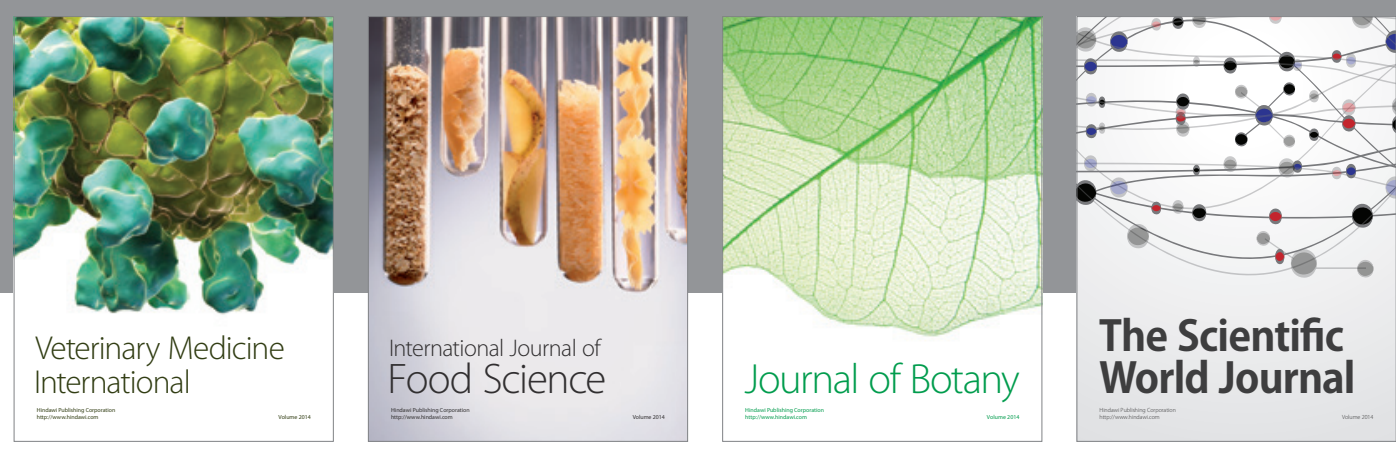

The Scientific World Journal
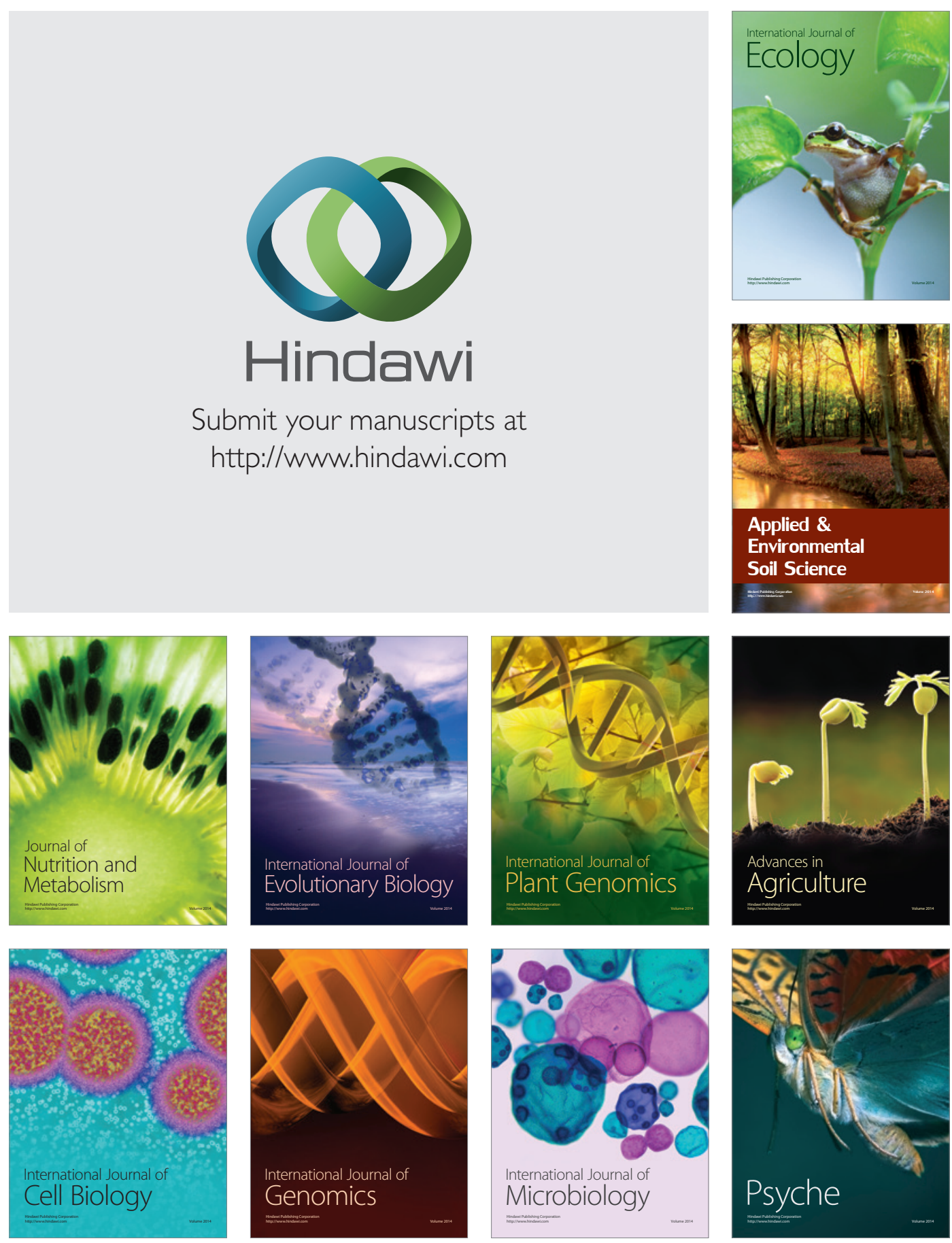